\title{
Abundance Frequency of Plant Species as Animal Feeds to Determine Ideal Cattle Grazing
}

\author{
Roni Yulianto ${ }^{1, a}$, Tran Dang Xuan ${ }^{1, c^{\star}}$, Kensuke Kawamura ${ }^{2, b}$, Jihyun Lim ${ }^{1, d}$, \\ Rena Yoshitoshi ${ }^{1, e}$, Fan Xinyan ${ }^{1, f}$, and Gong Zhe ${ }^{1, g}$
}

\author{
${ }^{1}$ Graduate School for International Development and Cooperation, Hiroshima University, 1-5-1 \\ Kagamiyama, Higashi Hiroshima, 739-8529, Japan. \\ 2Japan International Research Center for Agricultural Sciences (JIRCAS)

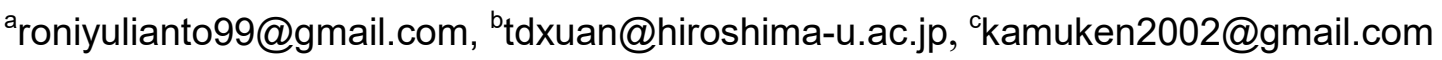 \\ dlimjihyun7@gmail.com, ${ }^{\mathrm{e}}$ rena.yoshi1210@gmail.com, ${ }^{\mathrm{f} x i n y a n f a n 5160 @ g m a i l . c o m, ~}$ \\ ggongzhe79@gmail.com \\ * Corresponding author email: tdxuan@hiroshima-u.ac.jp
}

Keywords: Appearance frequency, species abundance, grazing, animal feed, chlorophyll content

\begin{abstract}
The objectives of this study were to determine the dominant frequency of plant species, and provide useful information toward the conservation management of animal feed in grazing areas, Hiroshima, Japan. The numbers of plant species were 32 and 21 in spring and summer, respectively. The appearance frequency of plant species more than $50 \%$ in the spring, consist of Veronica arvensis (75.57\%), Trifolium repens (73.86\%), Paspalum dilatatum (69.32\%), Lamium purpureum (68.75\%), Trifolium dubium (65.34\%), Cerastium glomeratum (63.64\%), whereas in summer, it consists of Paspalum notatum (98.30\%), Trifolium repens (81.25\%), Paspalum dilatatum (78.98\%), and Kyllinga brevifolia (74.43\%). It was observed that the plant high of the plant species were 16.64 and $21.55 \mathrm{~cm}$; vegetation cover rates were 77.18 and $81.36 \%$; chlorophyll content were 41.72 and $36.28 \mathrm{mg} / \mathrm{g} \mathrm{Fw}$, and species numbers were 17.91 and 10.18, in spring and summer, respectively. Findings of this research propose that Trifolium repens (clover), Rumex japonicus (weed), and Paspalum dilatatum (grass) are dominant species in the studied areas that can be utilized as animal feeds.
\end{abstract}

\section{Introduction}

Level of the internal regulation ecosystem depends on plant species. The biodiversity of plants perform a variety of ecological service beyond the production of foods and feeds, including the recycling of nutrients, regulation of microclimate, local hydrological process, suppression of undesirable organisms, and detoxification of noxious chemicals [1]. The frequency of plant species is important as it has a prominent role in the life cycle of plants and animals. The supply of forage for cattle depends on pastures and it produces a wide variety of grass species which are superior in quantity and quality. At the same time, grass ecosystem balance and soil nutrient enrichment from their feces can be used as fertilizer for the grazing. Within varied pastures, the use of forage resource by herbivores does not necessarily coincide with either vegetation or phytosociological units of plant species. Due to their complexity, the plant-animal interactions considered on various processes occurring at different spatial and temporal scales [2]. Natural fertilization and transport of nutrients in animal's excreta is also significant for fertilizer of forage and adjacent biocenosis which may be used by herbivores for feeding and resting. It may be assumed that wild plants are adaptable to herbivores since plant species evolved together in grazing area. However, the intensity of defoliation and natural fertilization may adversely affect the grassland biocenosis.

Determination of a cattle grazing area is based on the appearance frequency and abundance of plant species that gives animal's decision of what and how much to eat under conditions where are 
widely controlled. The choice test has frequently used in ecological research [3], but fewer have been used to obtain new insights into the aspect of ruminant nutrients. Mixed grazing could be useful both for the quality of forage and performance of grazing animals as shown in simultaneous grazing of cattle. Extensively, mixed grazing has been practiced for many centuries and has had the profound effect on landscape and biodiversity. The properties of species assemblages include the number of co-occurring species richness, specific abundance patterns and compositional (e.g. community types), functional and structural characteristics of plant species in grazing area [4]. The problem when determining a cattle grazing area that is difficult to predict, especially within heterogeneous environments. So in this case, it is needed to determine the dominance of appearance frequency and abundance of plant species.

The objective of this study was to identify the species diversity and determine the dominant species in the studied grassland to supply animal feeds. Important spatial levels (patch and feeding station), and selective grazing that are influenced by preferred species and nutritive values of plants [5] are considered. Qualitative and structural factors, such as nutrient contents, digestibility and plant morphology interact with the choice of animals [6,7] and their behavior [8] are discussed. The relationships of the appearance frequency of various species to have impacts on plant community, chlorophyll, vegetation cover rate, and species number between spring and summer seasons are also determined.

\section{Materials and Methods}

\section{Study area}

The study area was conducted in a paddock, no. 8 (1.6 ha) at Setouchi Field Science Center, Graduate School of Biosphere Science, Hiroshima University, Japan (34 $23^{\prime} \mathrm{N}$ latitudes, $132^{\circ} 43^{\prime}$ E longitudes). The elevation ranged from 230 to $240 \mathrm{~m}$ above sea level, and the means slope angle was approximately 5 degree. The climate of the study site was a temperate zone with warm, humid summers, cool, and dry winters. The annual means temperature was $14.6^{\circ} \mathrm{C}$, and the annual precipitation was $621.9 \mathrm{~mm}$ in 2008 [9].

Frequency of the appearance of species

Observation of appearance frequency was conducted by a method [10] where floristic sociological approach on plant species are conceived as units recognized species by their total floristic composition. All formal descriptions of vegetation, followed by the Braun-Blanquet method required a table of observed species in the fields, providing a complete information of species for the vegetation communities. Among the species building up the floristic composition of a community, some species are better indicators than the others. Diagnostic species appearance is used to a hierarchical classification of which the association in the basic unit. The frequency of species determined how many species present and their productivity in a paddock. The productivity and species richness were determined by the abundance quality of frequency of various species. Species calculation in the paddock was defined by a square meter, where species was identified in each plot based on name and data record of species presence (presence $=1$ and absent $=0$ ). To determine the frequency of vegetation in each species data in each plot area, an observation model of [10] was used. Grazing mix forage, in fact, determines how many species are present in the abundant biodiversity vegetative structure that determine productivity and quality.

Vegetation analysis

To study the community composition was examined through a field observation during spring season (April-May) and summer season (August-September), 2015. Observation in the paddock was conducted using the line transect of $0-100 \mathrm{~m}$ to point every $10 \mathrm{~m}$ interval. The distance between each treatment used in a $1 \times 1 \mathrm{~m}$ quadrate $(n=11)$. One meter square made 16 parts of $0.25 \times 0.25$ m sub-quadrate [10]. 


\section{Data analysis}

The data was analyzed for the appearance frequency of various species, community high, vegetation cover rate, and species number to the methodology described by [10], all trials were conducted in thrice, using ANOVA (analysis of variance) with P values are determined at 0.01 and 0.05 .

\section{Results and Discussion}

Appearance frequency of various species

Grass species frequency is one characteristic of grass species community. It is mechanism generating stability. The nature of plant community at a place is determined by species to grow and develop in such environment [11]. In general, abundance frequency of the appearance of various species grass in the observation between spring and summer season was 32 in spring and 21 in summer (Table 1).

The maximum occurrence of species in spring and summer season could increase the productivity of plant species, due to the availability of moisture provided by rains and other environmental factors. A similar pattern of observations mirrored to present study was also mentioned by [12]. Because in the summer, some species were decreased, therefore in this case, the absorption and supplementation of nutrients can be increased according to the frequency of the appearance of species that conserve and breed grass in the grazing area. At moderate densities, the degree of discrimination among plant species may be slightly reduced, but it was increased in total amounts of tissue removal per plant composition due to selective foraging [13-15]. Alteration of grazing regimes affect the abundance of plant species $[16,17]$, but mechanisms of plant responses to plant morphological and physiological traits, are often not explicitly quantified.

Table 1. Appearance frequency of plant species between spring and summer seasons

\begin{tabular}{|l|c|c|c|c|c|}
\hline \multirow{2}{*}{ Species name } & \multirow{2}{*}{$\begin{array}{c}\text { Functional } \\
\text { group }\end{array}$} & \multicolumn{2}{|c|}{ Spring season } & \multicolumn{2}{c|}{ Summer season } \\
\cline { 3 - 6 } & & Abundance & $\begin{array}{c}\text { Frequency } \\
(\%)\end{array}$ & Abundance & $\begin{array}{c}\text { Frequency } \\
(\%)\end{array}$ \\
\hline Trifolium repens & Clover & 130 & 73.86 & 143 & 81.25 \\
\hline Trifolium dubium & Clover & 115 & 65.34 & 0 & 0 \\
\hline Oxalis corniculata & Clover & 48 & 27.27 & 33 & 18.75 \\
\hline Potentilla hebiichigo & Clover & 38 & 21.59 & 50 & 28.41 \\
\hline Hydrocotyle ramiflora maxim & Clover & 13 & 7.39 & 0 & 0 \\
\hline Potentilla anemonifolia & Clover & 9 & 5.11 & 12 & 6.82 \\
\hline Eleusine indica & Clover & 0 & 0 & 15 & 8.52 \\
\hline Total & Clover & $\mathbf{3 5 3}$ & $\mathbf{2 5 . 1 4}$ & $\mathbf{2 5 3}$ & $\mathbf{2 9 . 6 6}$ \\
\hline Veronica arvensis & Weed & 133 & 75.57 & 0 & 0 \\
\hline Lamium purpureum & Weed & 121 & 68.75 & 0 & 0 \\
\hline Cerastium glomeratum & Weed & 112 & 63.64 & 0 & 0 \\
\hline Veronica persica & Weed & 79 & 44.89 & 1 & 0.57 \\
\hline Geranium carolinianum & Weed & 57 & 32.39 & 0 & 0 \\
\hline Conyza sumatrensis & Weed & 37 & 21.02 & 3 & 1.7 \\
\hline Rumex japonicus & Weed & 33 & 18.75 & 45 & 25.57 \\
\hline Arabidopsis thaliana & Weed & 33 & 18.75 & 0 & 0 \\
\hline Vicia sativa & Weed & 18 & 10.23 & 0 & 0 \\
\hline Plantago asiatica & Weed & 8 & 4.55 & 9 & 5.11 \\
\hline Solidago canadensis & Weed & 8 & 4.55 & 4 & 2.27 \\
\hline Euphorbia helioscopia & Weed & 4 & 2.27 & 4 & 2.27 \\
\hline Capsella bursa-pastoris & Weed & 3 & 1.7 & 0 & 0 \\
\hline
\end{tabular}




\begin{tabular}{|l|c|c|c|c|c|}
\hline Stellaria & Weed & 3 & 1.7 & 0 & 0 \\
\hline Lamium amplexicaule & Weed & 3 & 1.7 & 0 & 0 \\
\hline Taraxacum & Weed & 2 & 1.14 & 1 & 0.57 \\
\hline Mazus miquelii & Weed & 1 & 0.57 & 0 & 0 \\
\hline Unkown & Weed & 0 & 0 & 3 & 1.7 \\
\hline Ranunculus cantoniensis & Weed & 0 & 0 & 2 & 1.14 \\
\hline Total & Weed & $\mathbf{6 5 5}$ & $\mathbf{4 6 . 6 5}$ & $\mathbf{7 2 . 0 0}$ & $\mathbf{8 . 4 4}$ \\
\hline Paspalum dilatatum & Grass & 122 & 69.32 & 139 & 78.98 \\
\hline Paspalum notatum & Grass & 84 & 47.73 & 173 & 98.3 \\
\hline Schedonorus arundinaceus & Grass & 66 & 37.5 & 16 & 9.09 \\
\hline Phleum pretense & Grass & 55 & 31.25 & 0 & 0 \\
\hline Poa annua & Grass & 25 & 14.2 & 0 & 0 \\
\hline Kyllinga brevifolia rottb & Grass & 22 & 12.5 & 131 & 74.43 \\
\hline Erigeron philadelphicus & Grass & 6 & 3.41 & 0 & 0 \\
\hline Poa sphondylodes & Grass & 6 & 3.41 & 0 & 0 \\
\hline Poa pratensis & Grass & 6 & 3.41 & 1 & 0.57 \\
\hline Carex leucochlora & Grass & 4 & 2.27 & 0 & 0 \\
\hline Digitaria ciliaris & Grass & 0 & 0 & 67 & 38.07 \\
\hline Elymus tsukushiensis & Grass & 0 & 0 & 1 & 0.57 \\
\hline Total & Grass & $\mathbf{3 9 6}$ & $\mathbf{2 8 . 2 1}$ & $\mathbf{5 2 8}$ & $\mathbf{6 1 . 9 0}$ \\
\hline Total all species & All group & $\mathbf{1 4 0 4}$ & $\mathbf{1 0 0 . 0 0}$ & $\mathbf{8 5 3 . 0 0}$ & $\mathbf{1 0 0 . 0 0}$ \\
\hline
\end{tabular}

In Table 1, the dominance of appearance frequency in Trifolium repens (clover), Rumex japonicus (weed), and Paspalum dilatatum (grass) among various species to grazer (i.e. grazing resistant species) influenced to the productivity of species. The frequency of various species can increase the productivity of plant species in grassland. The high-frequency plant species between spring and summer are important to predict the combination of traits that are typical to short grass increasing in abundance. When the grazing pressure was enhanced, tall grass is decreased and the tolerance ration to weed, grass, and clover can set for management to community structure and taxonomy, phylogenetic, and functional across plant species.

Community height in spring and summer seasons

The community height of grass was found significant $(\mathrm{P}<0.01)$ between spring $(16.64 \mathrm{~cm})$ and summer $(21.55 \mathrm{~cm})$ (Table 2). The community height in the spring is lower than summer. In the summer, the community high of plant species increased, because some species could not adapt to high temperature. The frequency distribution of plant density, cover, biomass per unit area and height, are used to measure for biological abundance of vegetation dominance, species composition and spatial patterns of vegetation on different plant communities [18].

Research has shown that depending on seasons, the density of grazing influences both species diversity, spatial heterogeneity, and vegetation structure [19, 20]. Structurally, a plant species becomes dominant from the other species may be affected from nutrient input and the heterogeneous of grazing patterns, that may maintain the substantial population of plant species in the present of grazing, as observed in the mesic savanna grassland, such as the Serengeti [21, 22]. 
Table 2. Community height, vegetation cover rate, chlorophyll, and species number between spring and summer seasons

\begin{tabular}{|l|c|c|c|c|c|c|}
\hline \multicolumn{1}{|c|}{ Features } & Season & Minimum & Maximum & Range & SD & $\begin{array}{c}\text { (N=11) with } \\
\text { mean } \pm \\
\text { standard error }\end{array}$ \\
\hline \multirow{2}{*}{ Community high $(\mathrm{cm})$} & Spring & 9.31 & 19.88 & 10.56 & 2.72 & $16.64 \pm 0.82 \mathrm{a}$ \\
\cline { 2 - 7 } & Summer & 14.25 & 32.69 & 18.44 & 6.32 & $21.55 \pm 1.91 \mathrm{~b}$ \\
\hline \multirow{2}{*}{ Vegetation cover rate (\%) } & Spring & 55.00 & 95.00 & 40.00 & 14.16 & $77.18 \pm 4.28 \mathrm{a}$ \\
\cline { 2 - 7 } & Summer & 60.00 & 95.00 & 35.00 & 11.64 & $81.36 \pm 3.52 \mathrm{a}$ \\
\hline \multirow{2}{*}{ Chlorophyll } & Spring & 38.81 & 45.54 & 6.74 & 1.96 & $41.72 \pm 0.59 \mathrm{a}$ \\
\cline { 2 - 7 } & Summer & 34.15 & 38.21 & 4.06 & 1.28 & $36.28 \pm 0.39 \mathrm{~b}$ \\
\hline \multirow{2}{*}{ Species number } & Spring & 12.00 & 21.00 & 9.00 & 2.59 & $17.91 \pm 0.78 \mathrm{a}$ \\
\cline { 2 - 7 } & Summer & 5.00 & 18.00 & 13.00 & 3.71 & $10.18 \pm 1.12 \mathrm{~b}$ \\
\hline
\end{tabular}

Values in the column with similar letters are not significantly different for each variable $(\mathrm{P}<0.01)$ and vegetation cover rate $(\mathrm{P}>0.05)$.

\section{Vegetation cove rate in spring and summer seasons}

Vegetation cover rate is an important part of an ecosystem and it has been used to estimate the monitoring of vegetation grows in a certain region. Table 2 shows that the vegetation cover rate between spring and summer was nonsignificant $(\mathrm{P}>0.05)$ between spring $(77.18 \%)$ and summer $(81.36 \%)$. The vegetation cover rate of plant species in the grazing area was high, because species appearance of grass in spring and summer can supply feed animal in the grazing area. Although there were more exotic species appeared in the grazing area, no causal link can be recognized between the reduction of species richness and ecosystem invisibility [23-25]. The exotic species appearance makes a positive contribution to native species and under the intense grazing pressure [26]. Most of plant species showed their dominance during spring and summer. Thus their frequent occurrence is varied among temperature, enough moisture, and micronutrients [27-29].

Difference between chlorophyll content between spring and summer

The chlorophyll content was determined by a SPAD 502, and it was significantly different between spring and summer $(\mathrm{P}<0.01)$. The result suggests that it should be possible to select the genotypic differences in levels of chlorophyll content between spring and summer seasons, as the chlorophyll content can reflect the heritability and growth of plant species in the grazing areas [30]. Species number between spring and summer seasons

The grazing could either influence or control the frequency, duration, and intensity of plant species in the grazing areas. The species number between spring and summer seasons is significantly different $(\mathrm{P}<0.01)$ (Table 2$)$. In summer season, species number decreased because plant species affected by some species which could not adapt to the summer and also influence to the quality of species diversity [31]. It has been reported that a doubling of $\mathrm{CO}_{2}$ in the atmosphere may increase the photosynthesis of the $\mathrm{C}_{4}$ plants $[32,33]$. Reduction of species number may be attributed to low nutrient availability and limit $\mathrm{CO}_{2}$ uptake [34-36]. The respiration rate per unit of dry weight of leaf area can indicated either the increase [37] or decrease [38], depending on plant species, because the process of photosynthesis could influence to species number in a grazing area.

\section{Conclusions}

The dominant frequency of plant species at the Setouchi Field, Hiroshima, Japan were found with Trifolium repens (clover), Rumex japonicas (weed), and Paspalum dilatatum (grass) could supply animal feeds in the grazing area. The dominant of plant species can enhance the production, simultaneously help to eliminate the dominance of exotic species to increase the productivity of animal feed supply in the studied area. 


\section{Acknowledgements}

The authors thank Indonesia Endowment Fund for Education (LPDP), Ministry of Finance, Republic of Indonesia, for the financial support. The authors declare that there is no conflict of interests.

\section{References}

[1] M.A. Altieri, Biodiversity and pest management in agroecosystems, Howarth Press, New York, 1994.

[2] L. Astigaraga, Peyraud, L. Delaby, Effect of nitrogen fertilizer rate and protein supplementation on the herbage intake and the nitrogen balance of grazing dairy cows, Animal Res. 4 (2002) 279-293.

[3] M.D. McMahon et al., Too close for comfort: Effect of trap spacing distance and pattern on statistical inference of behavioral choice test in the field, Entomologia Experimentalis et Applicata. 136 (2010) 66-71.

[4] R.J. Whittaker et al., Species richness on towards a general, theory of species diversity hierarchical theories of diversity, J. Biogeography. 28 (2001) 453-470.

[5] P. Dumont, Appearance of biomarkers of in-vitro ageing after successive stimulations of WI38 fibroblast with IL-1a and TNF-a: Senescence associated $\beta$-galactosidase activity and morphotype transition, J. Anat. 197 (2000) 529-537.

[6] I.J. Gordon, Intake and Diet Selection by Sheep Grazing Grass/Clover Patches, Proceedings of the $18^{\text {th }}$ International Grassland Society, 23 (1997), Session 5 ID NO. 25:5-11.

[7] A.J. Rook et al., Effect of long-term changes in relative resource availability on dietary preference of grazing sheep for perennial ryegrass and white clover, Grass and Forage Sci. 57 (2002) 54-60.

[8] M. Meisser et al., Foraging behavior and occupation pattern of beef cows on a heterogeneous pasture in the Swiss Alp, Czech J. Ani. Sci. 50 (2014) 84-95.

[9] K. Kawamura et al., Mapping herbage biomass and nitrogen status in an Italian ryegrass (Lolium multiflorum $L$ ) field using a digital video camera with balon system, Journal of Applied Remote Sensing. 5(1) (2011) 053562.

[10] Braun-Blanquet, Pflanzensosiologie: Grunzuge der Vegetation-skunde, 3te aufl. SpringVerlag, 1964.

[11] L.C. Bliss, Rosine and lipid contents in alpine tundra plants, Ecology. 43 (1962) 753-757.

[12] J. Sharma et al., Phosphorus solubilizing capabilities of microorganisms isolated from grapevine rhizophere and non rhizhosphere soil, J. Eco-Friendly Agric. 7 (2012) 38-42.

[13] Marquis, Effect of deer browsing on timber production in Alleghheny harwood forest of Northwestern in Pennsylvania. U.S, Forest Service Research Paper NE-475, 1981.

[14] N.G. Tilghman, Impact of white-tailed deer on forest regeneration in Northwestern Pennsylvania, J. Wildlife Manag. 53 (1989) 524-532.

[15] J.R. Brown, J.W. Stuth, How herbivory effects grazing tolerant and sensitive grass in a central Texas grassland: integrating plant response across hierachical level, Oikos. 67 (1993) 291298.

[16] C.P.H. Mulder C.P.H, Vertebrata herbivores and plants in the Arctic and subarctic: Effect on individuals, populations, communities and ecosystems, Perspectives in Plant Ecology, Evolution and Systematics. 2 (1989) 29-55.

[17] A.J. Hester et al., Impact of large herbivores on plant community structur dinamics and concervation, Cambridge University Press, Cambridge. (2006) 97-141.

[18] J. Chen, M. Shiyomi, Y. Yamamura, Frequency distribution model for spatial patterns of vegetation abundance, Ecol. Mod. 211 (2008) 403-410. 
[19] M.J. Metzger et al., The ATEAM vulnerability mapping tool, Quantitative approaches in systems analysis no. 27, CD-ROM publication, Office C.T. de Wit Graduate School for Production Ecology and Resource Concervation (PE and RC), Wagenigen, the Netherlands a climatic stratification of the environment of Europe, 2004.

[20] P.B. Adler, D.A. Raff, W.K. Launeroth, The effect of grazing on the spatial heterogeneity of vegetation, Oecol. 128(4) (2001) 465-479.

[21] S.J. McNaughton, Compensantory plant growth as response to herbivore, Oikos. 40 (1983) 329-336.

[22] D.J. Augustine, Mc Naughton, Ungulate effect on the functional species composition of plant communities: herbivore selectivity nd plant tolerance, J. Wildlife Manag. 62 (1988) 11651183.

[23] D. Tillman, The ecological consequences of change in biodiversity a search for general principles, Ecology. 80 (1999) 1455-1474.

[24] M.L. Rosenzweig, Species diversity in space and time. Cambridge University Press, Cambridge, 1995.

[25] D. Tillman, Community invisibility recruitment limitation and grassland biodiversity, Ecology. 78 (1997) 81-92.

[26] S. Kuksal et al., Phytosociological investigation and live from pattern of grazing lands under pine canopy in temperature zone, Northwest Himalaya India, Res. J. Bot. 4 (2009) 55-69.

[27] M. Nannete, L. Deacon, C. Robinson, Greater nitrogen and/or phosporus availability increase plant species cover and diversity at a High Artic popular semi desert, Polar Biol. 30 (2007) 559-570.

[28] S. Zaman, Effect of rainfall and grazing on vegetation yield and cover of two arid rangelands in Kuwait, Environ. Conserv. 24 (1997) 344-350.

[29] C. Skarpe, Structure of the woody vegetation in disturbed and undisturbed arid Savana, Botswana, Plant Ecology. 87 (1990) 11-18.

[30] R.A. Richards, Selectable traits to increase crop photosynthesis and yield of grain crop, J. Exp Bot. 51 (2000) 447-458.

[31] L.C. Hulbert, Fire and litter affect in undisturbed bluestem prairie in Kansan, Ecology. 50 (1969) 874-877.

[32] B.A. Kimball, Carbon-dioxide and agricultural yield: An assemblage and analysis of 430 prior observations, Agronomy J. 75 (1983) 779-778.

[33] Cao M, F.I. Woodward, Dynamic responses of terrestrial ecosystem carbon cycling to global climate change, Nature. 393 (1998) 249-252.

[34] D.T Tissue, W.C Oechel, Response of Eriphorum vaginatum to elevated $\mathrm{CO}_{2}$ and temperature in the Alaskan Tussock Tundra, Ecology. 68 (1987) 401-410.

[35] N.C.H. Fetcher et al., Long term elevation of atmospheric $\mathrm{CO}_{2}$ concentration and the carbon exchange rate saplings of Pinus taeda L. and Liquitambar styrachiflua L, Tree Physiol. 4 (1988) 255-262.

[36] R.F. Sage, T.D Sharkey, J.R. Seeman, Acclimation of photosynthesis to elevated $\mathrm{CO}_{2}$ in five $\mathrm{C}_{3}$ species, Plant Physiol. 89 (1989) 590-596.

[37] W.C. Oechel, B.R. Strain, Native species responses Chapter 5, pp. 118-154, in B.R. Strain and J.D Cure (eds), Direct Effect of Carbon Dioxide on Vegetation, State of the Art Report, U.S Department of Energy Office of Basic Energy Science, Carbon Dioxide Research Division. Washington, DC, 1985.

[38] R.M. Gifford, H. Lambers, J.I.L Morison, Respiration of crop species under $\mathrm{CO}_{2}$ enrichment, Physiologia Plantarum. 63 (1985) 351-356. 